\title{
Improving the knowledge of high school students about zoonotic diseases from pets in Medellín-Colombia
}

\author{
Natalia Uribe Corrales, Karen Velásquez Giraldo, Catalina María Saldarriaga Garcés and Angie Lorena Navarro Giraldo \\ Department of Agricultural Sciences, Faculty of Veterinary Medicine, Lasallian University Corporation (Unilasallista), \\ Caldas, Antioquia, Colombia. \\ Corresponding author: Natalia Uribe Corrales, e-mail: nuribe@unilasallista.edu.co \\ Co-authors: KVG: kvelasquez@unilasallista.edu.co, CMSG: csaldarriaga@unilasallista.edu.co, \\ ALNG: anavarro@unilasallista.edu.co \\ Received: 23-06-2021, Accepted: 10-11-2021, Published online: 09-12-2021
}

doi: www.doi.org/10.14202/vetworld.2021.3091-3098 How to cite this article: Corrales NU, Giraldo KV, Garcés CMS, Giraldo ALN (2021) Improving the knowledge of high school students about zoonotic diseases from pets in MedellínColombia, Veterinary World, 14(12): 3091-3098.

\begin{abstract}
Background and Aim: The "One Health" concept is a global strategy that recognizes that public health is related to animal health and the environment; however, the role of domestic animals and their involvement in the transmission of zoonoses is often underestimated. The aim of the study was to evaluate and improve the knowledge about zoonotic diseases of domestic animals in high school students from Medellín, Colombia.
\end{abstract}

Materials and Methods: A quasi-experimental intra-subject study was carried out. This study was conducted with $11^{\text {th }}$-grade students from four schools in Medellín, Colombia. A structured multiple-choice questionnaire was used from March 2021 to May 2021. The research had two phases, first, "naive" knowledge and learning. Then, descriptive, association, and comparative analysis were carried out using absolute and relative frequencies, Pearson's Chi-square test, and MacNemar's test with a value of $\mathrm{p}<0.05$ considered statistically significant.

Results: A research poll from 315 students of four private schools found that feeding their pets with raw food and leftovers cooked for human consumption were common practices; the results also show a lack of knowledge of their pets' immunization deworming status. It was understood that when the students were able to identify at least two symptoms of zoonoses, one route of its' transmission and two preventive measures, we found that only $12.49 \%$ of the polled students had proper knowledge of the disease in domestic animals. After conducting an educational strategy, the findings show a general increase in knowledge, leading us to accept that the academic approach was adequate to statistically increase the recognition of symptoms, routes of transmission and preventive measures $(\mathrm{p}=0.00)$.

Conclusion: The use of the theoretical lecture is effective to improve the understanding of the concept of transmission of diseases from animals to humans; in addition, the results show an increase of knowledge in high school students of the related symptoms, transmission routes, and preventive measures of zoonoses diseases in the region.

Keywords: cats, diseases, dogs, education, zoonoses.

\section{Introduction}

The "One Health" concept is a theoretical lecture strategy that recognizes that public health in humans is related to animal health and the environment. It requires the collaboration of physicians, veterinarians, environmental scientists, public health professionals, and wildlife experts; however, even knowing domestic animals can increase the presence of some diseases in humans, many times, the interaction of domestic animals is often underestimated [1,2]. During past decades, dogs and cats often spent a good part of their lives indoors in close contact with their owners. As a result, several zoonotic infectious diseases may be transmitted directly or indirectly from these species; thus, the World Small Animal

Copyright: Corrales, et al. Open Access. This article is distributed under the terms of the Creative Commons Attribution 4.0 International License (http://creativecommons.org/licenses/ by/4.0/), which permits unrestricted use, distribution, and reproduction in any medium, provided you give appropriate credit to the original author(s) and the source, provide a link to the Creative Commons license, and indicate if changes were made. The Creative Commons Public Domain Dedication waiver (http:// creativecommons.org/publicdomain/zero/1.0/) applies to the data made available in this article, unless otherwise stated.
Veterinary Association considered that there are three critical areas of "One Health" regarding domestic animals: The human-domestic animal bond, comparative medicine, and zoonotic infectious disease [2-4], therefore, the lack of awareness about zoonotic diseases and the role that pets can play with their interaction with humans, are some of the most important reasons for the outbreak of zoonotic diseases in people, improving awareness among the community should also improve the prevention and control of those diseases [5].

Regarding some interaction practices, some authors have shown that $50 \%$ of owners allow pets to lick their faces; $60 \%$ of the pets visit the bedroom; $45-60 \%$ (dogs-cats) are allowed on the bed; $18-30 \%$ (dogs-cats) sleep with their owner in bed and, among the cats, and $45 \%$ are allowed to jump onto the kitchen sink [6]. Those practices could be potential exposure to pathogens, reminding that animals can transmit microorganisms through direct or indirect contact through biting, licking, scratching, sneezing, coughing, handling body fluids, secretions, or contaminated bedding [7]. 
Other risk factors for infection include lack of regular and efficient deworming, absence of routine vaccination programs, poor hygiene practices, low socio-economic and educative factors, failure to regularly pick up and dispose of feces, lack of pets' population control measures, and consequent high numbers of free-ranging dog and cat populations [8]. Many of those factors can be mitigated by simple measures, such as hand hygiene and modification of animal contact behaviors. Therefore, being aware of the risks of getting a zoonotic disease and the measures that can reduce the risk are requirements that must be met $[8,9]$.

At present, many studies have evaluated the knowledge, attitude, and practices of the public toward pet ownership and associated zoonoses [10-14]; nonetheless, few studies show what the knowledge that students have related to zoonoses is. According to some authors, the student population is vulnerable to these diseases due to ignorance and confusion about what these diseases are (transmission mechanisms, effects on the human being's health, and the preventive measures), which increases the odds of getting sick [15].

Therefore, this study aimed to evaluate and improve the knowledge about zoonotic diseases of domestic animals in high school students from Medellín, Colombia.

\section{Materials and Methods}

\section{Ethical approval}

The Ethics Committee for Experimentation with Animals of the Lasallian University Corporation has approved this research.

\section{Study period and area}

The study was conducted from March 2021 to May 2021. Medellín is a Colombian municipality, capital of the region of Antioquia. It is the second most populated city in the country after Bogotá. In the widest part of the natural region known as Aburrá Valley, it is in the central Andes Mountain range. It extends on both banks of the Medellín River, which crosses it from south to north, and is the main nucleus of the metropolitan area of the Aburrá Valley [16]. The city had a population of 2,533,424 inhabitants during the year 2020. The latitude and altitude of the city result in a subtropical monsoon climate. The climate is temperate and humid, with an average temperature of $21.6^{\circ} \mathrm{C}[16,18]$ (Figure-1).

\section{Study design}

A quasi-experimental intra-subject study was conducted using the One Health approach. This study was carried out with $11^{\text {th }}$-grade students from four schools located in Medellín, Colombia.

\section{Sampling}

No sampling was carried out but instead worked with all the students who wanted to participate, who did not wish to participate, in the same way, we provided the educational component.

\section{Questionnaire}

A structured multiple-choice questionnaire was used for this study; it was written in Spanish. Thirty questionnaires had been pre-tested to assess the

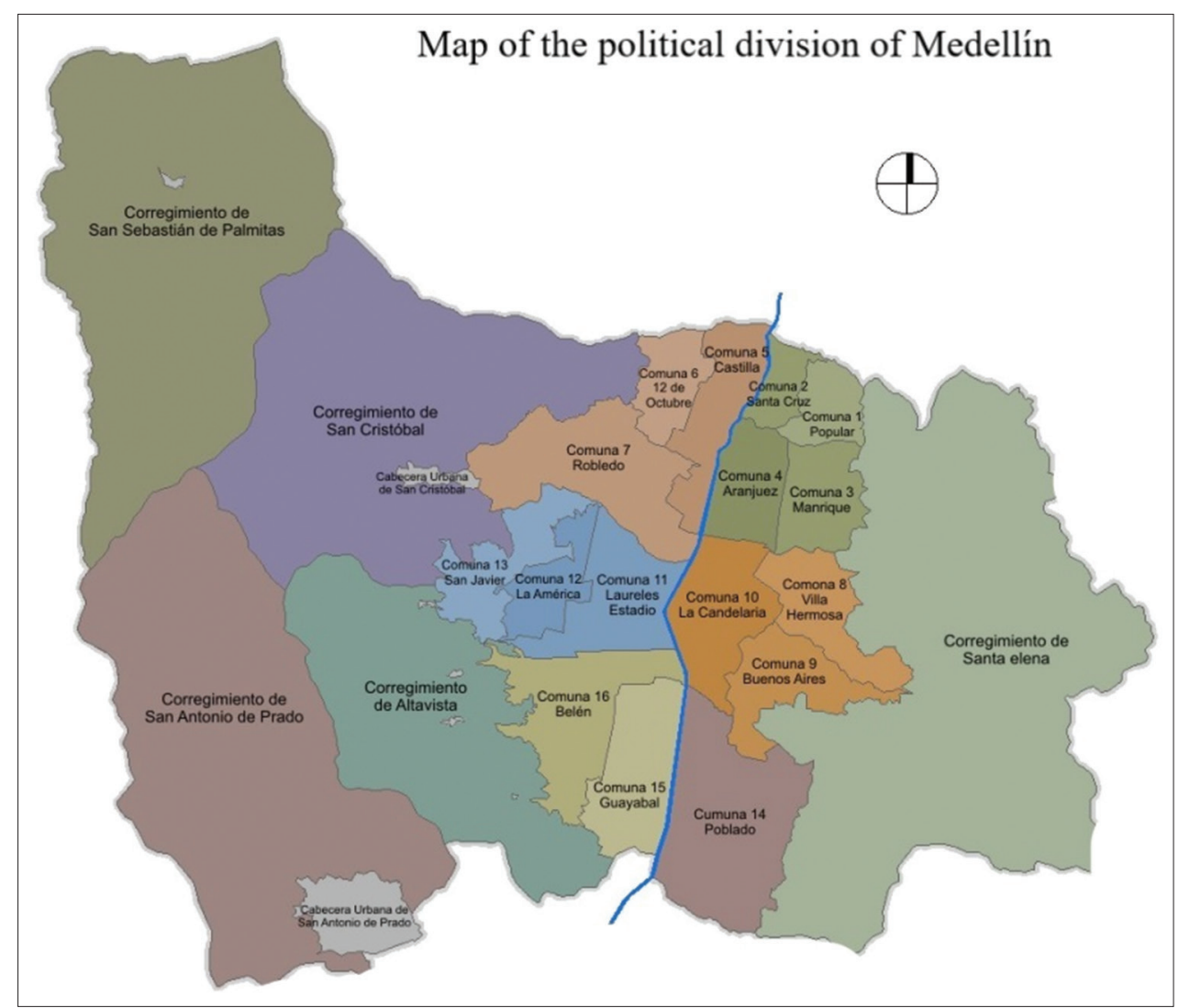

Figure-1: Map of Medellín [Source; https://commons.wikimedia.org/wiki/File: Corregimientos_de_Medellin.svg]. 
suitability of questions (written and multiple-choice answers). The final format took approximately 15-20 min to complete. The questionnaire consisted of 42 questions, divided into three sections: (i) Family structure (ii) animal species primary care, (iii) Zoonoses (symptoms, transmission mechanism, and preventive measures).

\section{Research process}

The research had two phases.

Phase 1 "Naive" knowledge the teachers at the schools provided the questionnaire link to the students without giving them an introductory lecture on the questionnaire's topics to assess the "prior knowledge" of the adolescents.

Phase 2 learning: Students attended a theoretical lecture session. The session consisted of $120 \mathrm{~min}$, by a virtual approach. We provided educational posters, slides, comics, and video clips with relevant content and messages [19]. Two weeks after the lecture, the same questionnaire of Phase 1 was again administered to assess the efficacy of the educational strategy and the students' learning rate. Cronbach's alpha for the 42-item knowledge scale before and after the intervention was 0.73 and 0.75 , respectively.

For knowledge assessment of the students, we asked about some endemic or historically critical zoonotic diseases in the country, such as rabies, brucellosis, leptospirosis, bartonellosis, leishmaniasis, giardiasis, toxoplasmosis, toxocariasis, ancylostomiasis, scabies, and dermatophytosis; the proper knowledge was only considered "correct" if the students were able to correctly identify at least two signs for each disease, one transmission mechanism, and at least two preventive measures.

\section{Statistical analysis}

Relative frequencies summarized demographic, basal knowledge, attitudes, and practices data. We use Pearson's Chi-square test to detect an association between demographic, attitudes, and practices variables and zoonoses knowledge; and MacNemar test to compare the baseline to the post-education intervention line, with a $p<0.05$ regarded as statistically significant. Analyses were performed with Stata ${ }^{\circledR}$ software version 15 (StataCorp LLC, TX, USA).

\section{Results}

We researched four private schools with a total of 315 students. Overall, the participants were mainly men; $82.22 \%$ were primarily from the poor or middle class, $78.41 \%$ had a pet, and the most common was a $\operatorname{dog} 50.79 \%$. For both (dogs and cats), males were primarily entire $50.53 \%$ and $61.90 \%$, although females were predominantly spayed $56.71 \%$ and $77.27 \%$, respectively. In addition, $95.23 \%$ of the respondents said they had heard the term zoonoses. The detailed demographic profile of the participants is presented in Table-1.

Relating to practices, $35 \%$ of the dogs are fed with raw or table scrap. An average of $39.49 \%$ of the students

Table-1: Frequency table for demographic and pets' variables.

\begin{tabular}{|c|c|c|c|}
\hline Variable & Category & Frequency & Percentage \\
\hline \multirow[t]{2}{*}{ Student Gender } & Male & 202 & 64.13 \\
\hline & Female & 113 & 35.87 \\
\hline \multirow[t]{2}{*}{ Home location } & Rural & 124 & 39.37 \\
\hline & Urban & 191 & 60.63 \\
\hline \multirow[t]{3}{*}{ Economic status } & Poor & 137 & 43.49 \\
\hline & Middle & 122 & 38.73 \\
\hline & High & 56 & 17.78 \\
\hline \multirow[t]{2}{*}{ Do you have a pet? } & Yes & 247 & 78.41 \\
\hline & No & 68 & 21.59 \\
\hline \multirow[t]{3}{*}{ What kind of pet do you have? } & Canine & 160 & 50.79 \\
\hline & Feline & 87 & 27.62 \\
\hline & Not have a pet & 68 & 21.59 \\
\hline \multirow[t]{3}{*}{ Where did you get your pet? } & Refugees & 110 & 44.53 \\
\hline & Animal Store & 95 & 38.46 \\
\hline & It was a gift & 42 & 17.00 \\
\hline \multirow[t]{2}{*}{ What is your canine's gender? } & Male & 93 & 58.12 \\
\hline & Female & 67 & 41.87 \\
\hline \multirow[t]{2}{*}{ What is your feline's gender? } & Male & 21 & 24.13 \\
\hline & Female & 66 & 75.86 \\
\hline \multirow[t]{4}{*}{ What is your canine's reproductive status? } & Entire male & 47 & 50.53 \\
\hline & Neutered male & 46 & 49.46 \\
\hline & Entire female & 29 & 43.28 \\
\hline & Spayed female & 38 & 56.71 \\
\hline \multirow[t]{4}{*}{ What is your feline's reproductive status? } & Entire male & 13 & 61.90 \\
\hline & Neutered male & 8 & 38.09 \\
\hline & Entire female & 15 & 22.72 \\
\hline & Spayed female & 51 & 77.27 \\
\hline \multirow[t]{2}{*}{ Have you ever heard the term zoonoses? } & Yes & 300 & 95.23 \\
\hline & No & 15 & 4.76 \\
\hline
\end{tabular}


did not know how often their pets had been vaccinated or dewormed. Regarding fleas or ticks, $81.25 \%$ of the students reported seeing them on their dogs and $67.82 \%$ on their cats. The detailed knowledge and practices of the participants are presented in Table- 2 .

In addition, $72.28 \%$ of the students had experienced mouth contact with their pets; $64.36 \%$ reported contact with pet feces. Finally, we found that $62.38 \%$ washed their hands after having contact with their pets, although just $55.56 \%$ of them do that consistently; $37.62 \%$ never washed their hands after having contact with their pets (Table-3).

At Phase 1, 100\% of the students had heard about rabies; however, regarding other diseases, a low percentage of the participants had heard about them (Figure-2). Although a low percentage of students had heard about some diseases, the knowledge about symptoms, route of transmission, and preventive measures was lower. Scabies, rabies, and toxoplasmosis were the conditions where they showed more ability $23.01 \%, 22.70 \%$, and $20.31 \%$, respectively (Figure-3). We did not find any association between demographic, attitudes, and practices variables and zoonoses knowledge.
After the lecture, global knowledge increased to an average of $61.48 \%$, being the highest in rabies $(80.63 \%)$ and the lowest in leptospirosis $(42.86 \%)$. Dermatophytosis was the disease that achieved the most significant increase of knowledge, $67.32 \%$, followed by rabies and leishmaniasis, the ability increased by $57.93 \%$ and $54.43 \%$, respectively. As shown in Figure-3 and Table-4, the educational strategy effectively improved their knowledge in recognizing symptoms,

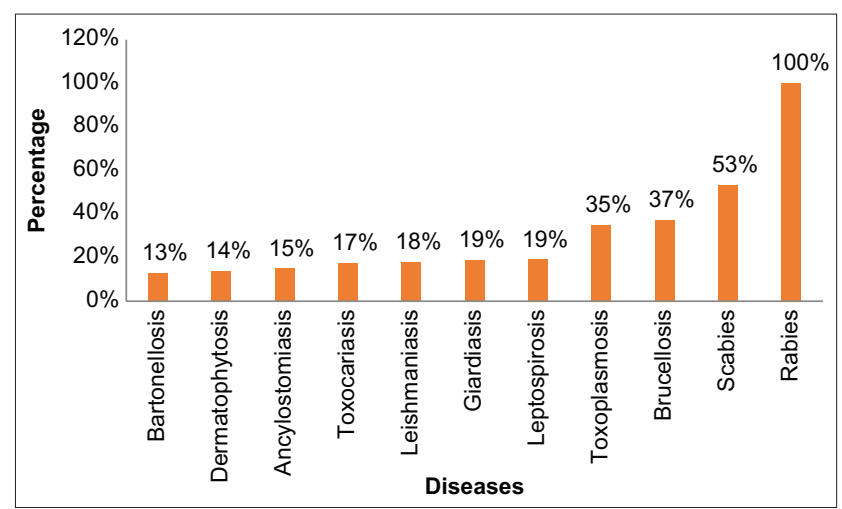

Figure-2: Percentage of students who had heard about different zoonotic diseases in Phase 1.

Table-2: Knowledge and practices of the students on pet farming.

\begin{tabular}{|c|c|c|c|c|}
\hline Variable & Specie & Category & Frequency & Percentage \\
\hline \multirow[t]{5}{*}{ What do you feed your pet? } & \multirow[t]{3}{*}{ Canine } & Raw & 16 & 10.00 \\
\hline & & Table scrap/human food & 40 & 25.00 \\
\hline & & Commercial food & 104 & 65.00 \\
\hline & \multirow[t]{2}{*}{ Feline } & Commercial food & 56 & 64.37 \\
\hline & & Table scrap/human food & 31 & 35.63 \\
\hline \multirow{4}{*}{$\begin{array}{l}\text { See a veterinarian regularly (at least once a } \\
\text { year)? }\end{array}$} & \multirow[t]{2}{*}{ Canine } & Yes & 98 & 61.25 \\
\hline & & No & 62 & 38.75 \\
\hline & \multirow[t]{2}{*}{ Feline } & Yes & 52 & 59.77 \\
\hline & & No & 35 & 40.23 \\
\hline \multirow[t]{4}{*}{ How often is your pet vaccinated? } & \multirow[t]{2}{*}{ Canine } & Annually & 98 & 61.25 \\
\hline & & Do not Know & 62 & 38.75 \\
\hline & \multirow[t]{2}{*}{ Feline } & Annually & 52 & 59.77 \\
\hline & & Do not Know & 35 & 40.23 \\
\hline \multirow[t]{5}{*}{ How often does your pet deworm? } & \multirow[t]{3}{*}{ Canine } & Annually & 69 & 43.13 \\
\hline & & Every 3 or 4 months & 29 & 18.13 \\
\hline & & Do not remember & 62 & 38.75 \\
\hline & \multirow[t]{2}{*}{ Feline } & Every 3 or 4 months & 52 & 59.77 \\
\hline & & Do not know & 35 & 40.23 \\
\hline \multirow[t]{4}{*}{ Have you seen fleas or ticks on your pet? } & \multirow[t]{2}{*}{ Canine } & Yes & 130 & 81.25 \\
\hline & & No & 30 & 18.75 \\
\hline & \multirow[t]{2}{*}{ Feline } & Yes & 59 & 67.82 \\
\hline & & No & 28 & 32.18 \\
\hline
\end{tabular}

Table-3: Sanitation and pet contact-related attitudes of the respondents.

\begin{tabular}{llcc}
\hline Variable & Category & Frequency & Percentage \\
\hline Having mouth contact with any part of your pet & Yes & 228 & 72.28 \\
& No & 87 & 27.72 \\
Touching or having any contact with your pet & Yes & 203 & 64.36 \\
faces & No & 112 & 35.64 \\
Do you (any member of the family) wash their & Yes & 196 & 62.38 \\
hands after touching your pet? & No & 119 & 37.62 \\
How often & Always & 28 & 14.29 \\
& Ssually & 59 & 30.16 \\
\hline
\end{tabular}




\begin{tabular}{|c|c|c|c|c|c|c|c|}
\hline \multirow{2}{*}{$\begin{array}{l}\text { Knowledge of zoonoses } \\
\text { after educational } \\
\text { intervention }\end{array}$} & \multicolumn{3}{|c|}{$\begin{array}{l}\text { Knowledge of zoonoses before } \\
\text { educational intervention }\end{array}$} & \multirow[t]{2}{*}{$\underset{\text { chi }^{2}}{\text { McNemar's }}$} & \multirow[t]{2}{*}{ p-value } & \multirow[t]{2}{*}{$\begin{array}{l}\text { Odds } \\
\text { ratio }\end{array}$} & \multirow{2}{*}{$\begin{array}{c}95 \% \\
\text { Confidence } \\
\text { interval }\end{array}$} \\
\hline & $\begin{array}{c}\text { With } \\
\text { knowledge }\end{array}$ & $\begin{array}{c}\text { Without } \\
\text { knowledge }\end{array}$ & Total & & & & \\
\hline \multicolumn{8}{|l|}{ Rabies } \\
\hline With knowledge & 35 & 219 & 254 & 204.45 & 0.00 & 43.8 & $15.15-205.44$ \\
\hline Without knowledge & 5 & 56 & 61 & & & & \\
\hline Total & 40 & 275 & 315 & & & & \\
\hline \multicolumn{8}{|l|}{ Brucellosis } \\
\hline With knowledge & 46 & 169 & 215 & 169.00 & 0.00 & 38.5 & $31.39-69.75$ \\
\hline Without knowledge & 1 & 99 & 100 & & & & \\
\hline Total & 47 & 268 & 315 & & & & \\
\hline \multicolumn{8}{|l|}{ Leptospirosis } \\
\hline With knowledge & 25 & 110 & 135 & 70.13 & 0.00 & 6.87 & $3.51-15.14$ \\
\hline Without knowledge & 16 & 164 & 180 & & & & \\
\hline Total & 41 & 274 & 315 & & & & \\
\hline \multicolumn{8}{|l|}{ Bartonellosis } \\
\hline With knowledge & 37 & 116 & 153 & 101.83 & 0.00 & 23.20 & $7.88-109.88$ \\
\hline Without knowledge & 5 & 157 & 162 & & & & \\
\hline Total & 42 & 273 & 315 & & & & \\
\hline \multicolumn{8}{|l|}{ Leishmaniasis } \\
\hline With knowledge & 44 & 146 & 190 & 66.48 & 0.00 & 4.05 & $2.51-6.82$ \\
\hline Without knowledge & 36 & 89 & 125 & & & & \\
\hline Total & 80 & 235 & 315 & & & & \\
\hline \multicolumn{8}{|l|}{ Giardiasis } \\
\hline With knowledge & 88 & 96 & 184 & 84.64 & 0.00 & 24.00 & $7.28-146.02$ \\
\hline Without knowledge & 4 & 127 & 131 & & & & \\
\hline Total & 92 & 223 & 315 & & & & \\
\hline \multicolumn{8}{|l|}{ Toxoplasmosis } \\
\hline With knowledge & 56 & 139 & 195 & 116.74 & 0.00 & 17.37 & $7.20-55.30$ \\
\hline Without knowledge & 8 & 112 & 120 & & & & \\
\hline Total & 64 & 251 & 315 & & & & \\
\hline \multicolumn{8}{|l|}{ Toxocariasis } \\
\hline With knowledge & 24 & 135 & 159 & 110.25 & 0.00 & 15.00 & $6.48-44.18$ \\
\hline Without knowledge & 9 & 147 & 156 & & & & \\
\hline Total & 33 & 282 & 315 & & & & \\
\hline \multicolumn{8}{|l|}{ Ancylostomiasis } \\
\hline With knowledge & 57 & 119 & 176 & 89.72 & 0.00 & 10.81 & $4.97-28.41$ \\
\hline Without knowledge & 11 & 128 & 139 & & & & \\
\hline Total & 68 & 247 & 315 & & & & \\
\hline \multicolumn{8}{|l|}{ Scabies } \\
\hline With knowledge & 86 & 149 & 235 & 102.76 & 0.00 & 8.27 & $4.43-17.21$ \\
\hline Without knowledge & 18 & 62 & 80 & & & & \\
\hline Total & 104 & 211 & 315 & & & & \\
\hline \multicolumn{8}{|l|}{ Dermatophytosis } \\
\hline With knowledge & 80 & 158 & 238 & 127.86 & 0.00 & 14.36 & $6.68-37.44$ \\
\hline Without knowledge & 11 & 66 & 77 & & & & \\
\hline Total & 91 & 224 & 315 & & & & \\
\hline
\end{tabular}

route of transmission, and preventive measures in all the conditions. Nonetheless, a substantial proportion of the respondents still did not have the proper knowledge.

\section{Discussion}

It is known that pets have a positive effect on human health. However, the human-pet bond faces many challenges that increase the transmission of infection between pets and humans. It is mainly due to the increasing contact between humans and pets and pathogens secreted by animals in the shared environment. Thus, animals can spread more than 6 of every 10 known infectious diseases, and 3 of every 4 new or emerging infectious diseases in people come from animals [20-23].
The Naïve Knowledge of adolescents shows that they have a significant lack of knowledge in understanding zoonoses. This study found that had heard about zoonotic was higher than previous studies (95.23\%). In Ethiopia, the information shows that $76.8 \%$ of high school students had heard about zoonoses [24]. In Malaysia, the 11\% [25], in a previous study in Nariño, Colombia, and Usme, the authors found that $63 \%$ and $74.6 \%$ of the respondent had heard about the term zoonoses [26,27], in Austria, Germany, Slovenia, Mauritius, and Japan $67.84 \%$ of adolescents know the meaning of the term zoonoses [28]. However, in Brazil, only $28.2 \%$ had heard the term zoonosis [29]. 


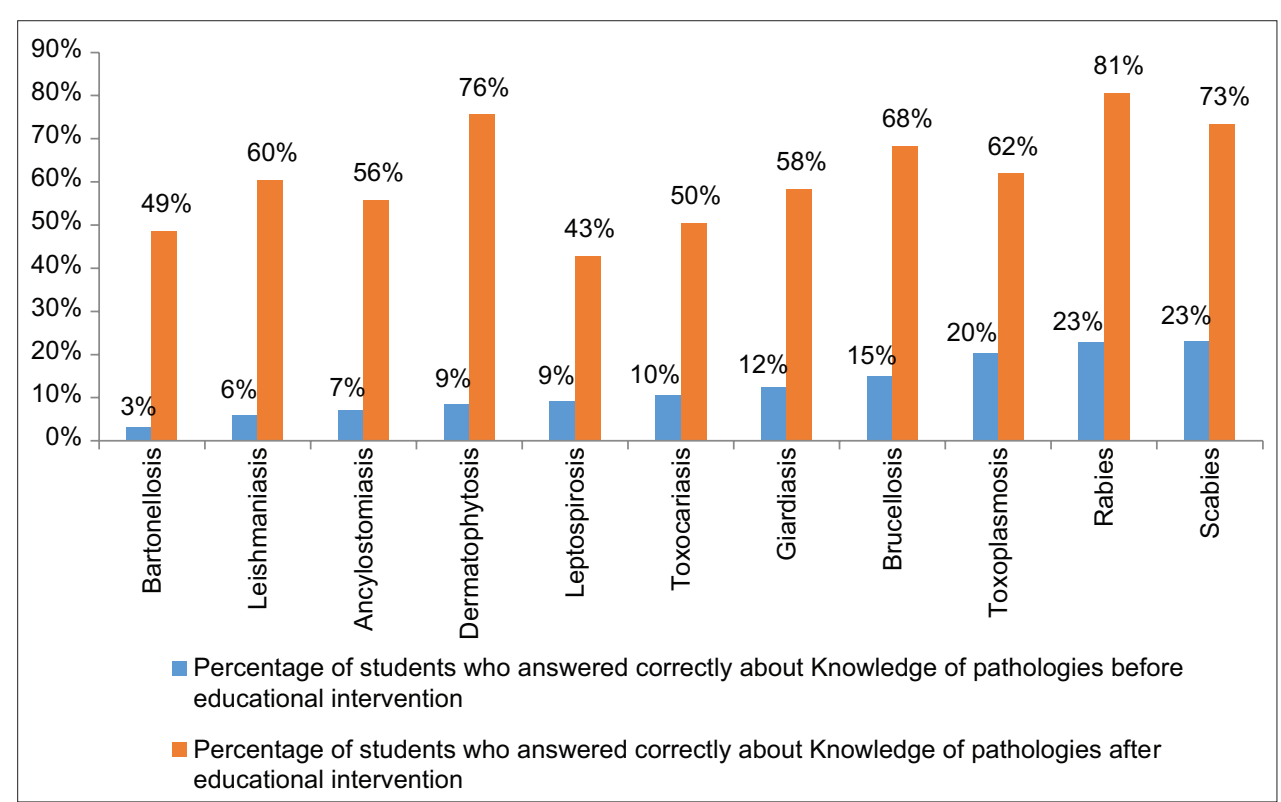

Figure-3: Knowledge before and after educational intervention from 315 students in Medellín.

In addition, an average of knowledge about zoonoses was found $(12.49 \%)$. The lower cognitive degree in diseases caused by bacteria was related to Bartonella (3.33\%) and Leptospira (9.13\%). Parasite diseases such as Leishmania (5.89\%) and Ancylostoma $(6.89 \%)$ also had lower cognitive degrees. The higher degree of knowledge was $(23.01 \%)$ for scabies and rabies $(22.70 \%)$, like other authors in which the main zoonosis recognized by the students was rabies. A high proportion did not identify leishmaniasis, toxoplasmosis as zoonoses $[10,13,30]$. This situation is bothering and indicates that most of the students have a low or medium knowledge relating to zoonotic diseases [10,12,13,15,19,30,31], being worrying considering that zoonoses are a reality in the population, and lack of basic knowledge about these diseases is due to the scarce delivery of information to communities [20,23,32-34].

After the lecture, the global knowledge increased to an average of $61.48 \%$, being the highest in rabies $(80.63 \%)$. Some studies show that health education and hygiene instruction are often underestimated, especially with children and adolescents. However, some authors have shown that health education is almost sufficient to avoid zoonoses such as toxocariasis and others [26,27,35-37].

Regarding practices and attitudes performed by the students, this study revealed that $38.75 \%$ of students who have a dog do not take their dog to veterinary service regularly, nor the $40.23 \%$ of the students who have a cat. This result indicates that most pet owners' in Medellín give little care for their pet's health. In addition, some respondents fail to vaccinate and deworm their animals, presumably since they do not have enough money to go to the veterinarian for preventive check or invest in preventative measures.

In addition, 35\% of the respondents fed their dogs with raw food or table scrap food. This result is higher than in Canada, which reported that only $28 \%$ of dog owners fed raw food like eggs, meat, or animal products [38]. Still, our results are lower than in Ethiopia, in which $92.1 \%$ of the dog owners reported this practice [12]. This difference is mainly due to differences in the economic status of pet owners in countries such as Colombia or Ethiopia.

In addition, we found that some practices such as having mouth contact with the animals, touching pet feces, and do not always wash their hands after contact with their pets are similar to results found in Ethiopia [39], where $14.9 \%$ of high school students haring the same house with animals; $24.2 \%$ feed their pets with raw food, and $16.7 \%$ did not vaccinate their pets; and in Italy, Austria, Germany, Slovenia, Mauritius, and Japan almost $24 \%$ of the students are unaware that pets must be dewormed [28], those results exposes them to a tangible risk of being infected by zoonotic parasitic diseases such as Giardia or Toxocara.

Hence, continuous community motivation, better education, and governmental officials' awareness about zoonoses are crucial to improving general knowledge because pets can transmit different diseases by infected saliva, contaminated urine or feces, or direct contact [40].

Hand hygiene plays an essential role in reducing the risk of zoonotic infections. In this study, the reported hand washing after having direct contact with the pet was moderate $62.38 \%$. In contrast to this finding, most pet owners in developed countries wash their hands less frequently after contacting their pets. For example, in the United States, $45 \%$ of the people reported washing their hands after contact with pets [41]; in the Netherlands, said that $50 \%$ of dog owners washed their hands after having contact with their dogs, and only $15 \%$ of dog owners in Cheshire, England [6,7]. One possible explanation for this difference could be as most pet owners in developed 
countries give much attention to farming, sanitation, and the health of their pets.

As awareness of the risk of zoonotic diseases is a prerequisite for effective prevention, the public's limited knowledge of zoonotic illness is a serious concern. The little understanding of zoonotic diseases in the current study is not surprising because, unfortunately, these topics are not part of the curriculums of high schools in Colombia. Therefore, it is the responsibility of veterinarians to educate pet owners about the importance of properly property their pets and implementing recommended hygiene measures (i.e., avoiding raw pet food, mouth contact, and not washing hands). The One Health concept concerning zoonoses and pets is clear about why veterinarians, physicians, and public health authorities need to work together to ensure that all decisions and implemented measures have an impact on the health of humans, animals, and the environment $[2,42,43]$.

\section{Conclusion}

We observed a positive impact mainly on the knowledge of the symptoms, transmission routes, and preventive measures of zoonotic disease. However, despite meeting the proposed objectives, some high school students still do not identify some zoonoses, so it is essential to emphasize zoonoses that the population is exposed to in the curriculum of the high schools. This finding should warn city managers to develop campaigns to educate the general community and reduce zoonoses' progression.

The usefulness of the theoretical lecture has its effectiveness in understanding the concept of the transmission of diseases that can transmit animals to humans. In this case, only one academic virtual class was enough to increase the knowledge related to symptoms, transmission mechanisms, and preventive measures for zoonotic diseases from pets.

\section{Limitations of the study}

The study was based on four schools that allowed us to share our knowledge with the students. Preferably, it would have been better if the pandemic situation permitted to increase the sample size in other schools and make the lecture and activities face to face to improve the knowledge of the high school students.

\section{Authors' Contributions}

NUC: Conceptualization, formal analysis, methodology, and drafted and revised the manuscript. KVG, CMSG, and ALNG: Educative intervention. NUC, KVG, CMSG, and ALNG: Investigation and drafted the manuscript. All authors read and approved the final manuscript.

\section{Acknowledgments}

The authors express their gratitude to Lasallian University Corporation (Unilasallista), Colombia, for providing the necessary facilities for this study. The authors did not receive any funds for this study.

\section{Competing Interests}

The authors declare that they have no competing interests.

\section{Publisher's Note}

Veterinary World remains neutral with regard to jurisdictional claims in published map and institutional affiliation.

\section{References}

1. One Health Initiative, 'One Health Initiative'. (2021) One Health Initiative. Available from: https://www.onehealthinitiative.com Retrieved on 09-06-2021.

2. Overgaauw, P.A.M., Vinke, C.M., van Hagen, M.A.E. and Lipman, L.J.A. (2020) A one health perspective on the human-companion animal relationship with emphasis on zoonotic aspects. Int. J. Environ. Res. Public. Health, 17(11): 3789

3. WSAVA. (2020) Recomendaciones Sobre Vacunación Para Los Profesionales Latinoamericanos De Pequeños Animales: Un Informe Del Grupo De Directrices de Vacunación de WSAVA. Available from: https://www. wsava.org/wp-content/uploads/2020/10/recommendations-on-vaccination-for-latin-american-small-animal-practitioners-spanish.pdf. Retrieved on 12-05-2021.

4. Baede, V.O., Broens, E.M., Spaninks, M.P., Timmerman, A.J., Graveland, H., Wagenaar, J.A., Duim, B. and Hordijk, J. (2017) Raw pet food as a risk factor for shedding of extended-spectrum beta-lactamase-producing Enterobacteriaceae in household cats. PLoS One, 12(11): e0187239.

5. Greter, H., Jean-Richard, V., Crump, L., Béchir, M., Alfaroukh, I.O., Schelling, E., Bonfoh, B., Zinsstag, J. (2014) The benefits of "One Health" for pastoralists in Africa. Onderstepoort J. Vet. Res., 81(2): E1-E3.

6. Overgaauw, P.A., van Zutphen, L., Hoek, D., Yaya, F.O., Roelfsema, J., Pinelli, E., van Knapen, F. and Kortbeek, L.M. (2009) Zoonotic parasites in fecal samples and fur from dogs and cats in The Netherlands. Vet. Parasitol., 163(1): 115-122.

7. Westgarth, C., Pinchbeck, G.L., Bradshaw, J.W.S., Dawson, S., Gaskell, R.M. and Christley, R.M. (2008) Dog-human and dog-dog interactions of 260 dog-owning households in a community in Cheshire. Vet. Rec., 162(14): 436-442.

8. Stull, J.W., Brophy, J. and Weese, J.S. (2015) Reducing the risk of pet-associated zoonotic infections. Can. Med. Assoc. J., 187(10): 736-743.

9. The National Association of State Public Health Veterinarians Animal Contact Compendium Committee. (2017) Compendium of Measures to Prevent Disease Associated with Animals in Public Settings, 2017. Available from: http://www.nasphv.org/documents/animalcontactcompendium2017.pdf. Retrieved on 20-05-2021

10. Ali, A., Ahmed, E. and Sifer, D. (2014) A study on knowledge, attitude, and practice of rabies among residents in Addis Ababa, Ethiopia. Ethiop. Vet. J., 17(2): 19.

11. Stull, J.W., Peregrine, A.S., Sargeant, J.M. and Weese, J.S. (2012) Household knowledge, attitudes and practices related to pet contact and associated zoonoses in Ontario, Canada. BMC Public Health, 12(1): 553.

12. Kiflu, B., Abdurahaman, M., Alemayehu, H. and Eguale, T. (2016) Investigation on public knowledge, attitude, and practices related to pet management and zoonotic canine diseases in Addis Ababa, Ethiopia. Ethiop. Vet. J., 20(1): 67-78.

13. Baneth, G., Thamsborg, S.M., Otranto, D., Guillot, J., Blaga, R., Deplazes, P. and Solano-Gallego, L. (2016) Major parasitic zoonoses associated with dogs and cats in Europe. J. Comp. Pathol., 155(1): S54-S74.

14. Bingham, G.M., Budke, C.M. and Slater, M.R. (2010) Knowledge and perceptions of dog-associated zoonoses: 
Brazos County, Texas, USA. Prev. Vet. Med., 93(2-3): 211-221.

15. Kakkar, M., Ramani, S., Menon, G., Sankhe, L., Gaidhane, A. and Krishnan, S. (2011) Zoonoses? Not sure what that is. An assessment of knowledge of zoonoses among medical students in India. Trans. R. Soc. Trop. Med. Hyg., 105(5): 254-261.

16. Gobernación de Antioquia. (2012) Sobre el Valle de Aburrá. Gobernación de Antioquia. Available from: https://www. web.archive.org/web/20130512081802; http://www.antioquia.gov.co/index.php/registrar/7052-sobre-el-valle-deaburra. Retrieved on 11-05-2021

17. Departamento Administrativo Nacional de Estadística. (2020) Proyecciones de Poblaciones. Available from: https:/www.dane.gov.co/index.php/estadisticas-por-tema/ demografia-y-poblacion/proyecciones-de-poblacion. Retrieved on 11-05-2021

18. Alcaldia de Medellín. (2020) Medellín y su Población. Alcaldia de Medellín. Available from: https://commons. wikimedia.org/wiki/File: Corregimientos_de_Medellin. svg. Retrieved on 11-05-2021

19. Maaoui, F., Moumni, I. and Mouelhi, L. (2018) Empowering Tunisian school students to prevent food and zoonotic diseases. Epidemiol. Open Access, 8(3): 357.

20. Center for Diseases Control and Prevention. (2020) Zoonotic Diseases. Available from: https://www.cdc.gov/onehealth/ basics/zoonotic-diseases.html. Retrieved on 09-06-2021.

21. OMS/OPS. (2020) Zoonosis. Available from: https:// www.who.int/es/news-room/fact-sheets/detail/zoonoses. Retrieved on 02-10-2020.

22. Organización Mundial de Sanidad Animal. (2019) Terrestrial Animal Health Code. Vol. 1. Paris, France: Organización Mundial de Sanidad Animal. Available from: https://www. oie.int/index.php?id $=169 \& \mathrm{~L}=2 \&$ htmfile $=$ chapitre_criteria_diseases.htm. Retrieved on 26-10-2020.

23. Center for Diseases Control and Prevention. (2020) About Pets and People: Healthy Pets, Healthy People. Available from: https://www.cdc.gov/healthypets/health-benefits/ index.html. Retrieved on 10-06-2021.

24. Gezmu, M., Bsrat, A. and Mekuria, A. (2017) Assessment of community knowledge, attitude and practice on zoonotic disease in and around Dodola town, West Arsi Zone, Ethiopia. Ethiop. J. Vet. Sci. Anim. Prod., 1(1): 57-65.

25. Andiappan, H., Nissapatorn, V., Sawangjaroen, N., Khaing, S.L., Salibay, C.C., Cheung, M.M., Dungca, J.Z., Chemoh, W., Xiao Teng, C., Lau, Y.L. and Mat Adenan, N.A. (2014) Knowledge and practice on toxoplasma infection in pregnant women from Malaysia, Philippines, and Thailand. Front. Microbiol., 5(1): 291.

26. Martínez, J., Benavides, J. and Timarán, D. (2015) Assessment of the knowledge about zoonotic diseases in high school students of educational institutions from the rural area of the municipality of Pasto, Nariño. Vet. Zootec., 8(2): 110.

27. Herrera, D.C.V. and Rodríguez, I.M.V. (2014) Evaluación Del Conocimiento y la Percepción Sobre Las Zoonosis Asociadas a Caninos en Propietarios de Mascotas en las Localidades de Usaquén y Usme. p141.

28. Zucca, P., Rossmann, M.C., Dodic, M., Ramma, Y., Matsushima, T., Seet, S., Holtze, S., Bremini, A., Fischinger, I., Morosetti, G., Sitzia, M., Furlani, R., Greco, O., Meddi, G., Zambotto, P., Meo, F., Pulcini, S., Palei, M. and Zamaro, G. (2021) What do adolescents know about one-health and zoonotic risks? A school-based survey in Italy, Austria, Germany, Slovenia, Mauritius, and Japan. Front. Public Health, 9(2): 658876.

29. Lima, A.M.A., Alves, L.C., da Glória Faustino, M.A. and de Lira, N.M.S. (2010) Perception of the zoonosis and responsible pet care by the parents from public schools kindergarten located at metropolitan region of Recife, northeast of Brazil. Ciênc. Saúde Coletiva, 15(1): 1457-1464.

30. Echeverri, C.A.G. and Ruiz Cortés, Z.T. (2009) Universidad de Antioquia, M. Olivera Ángel, and Universidad de Antioquia, 'Brucella canis in Medellin (Colombia), a current problem. Rev. UDCA Actual. Divulg. Cientifica, 12(1): 210-220.

31. do Nascimento Silva, F.A., Quessada, A.M., da Silva Magalhães, C., Lima, D.A.S., Lima, W.C. and Rodrigues, N.M. (2019) Knowledge of students of public schools about responsible ownership of pets and zoonoses. Acta Vet. Bras., 13(2): 51-54.

32. McNamara, J., Drake, J., Wiseman, S. and Wright, I. (2018) Survey of European pet owners quantifying endoparasitic infection risk and implications for deworming recommendations. Parasit. Vectors, 11(1): 571.

33. Miró, G., Gálvez, R., Montoya, A., Delgado, B. and Drake, J. (2020) Survey of Spanish pet owners about endoparasite infection risk and deworming frequencies. Parasit. Vectors, 13(1): 101.

34. Chalkowski, K., Wilson, A.E., Lepczyk, C.A. and Zohdy, S. (2019) Who let the cats out? A global meta-analysis on risk of parasitic infection in indoor versus outdoor domestic cats (Felis catus). Biol. Lett., 15(4): 20180840.

35. Aragón, V. and León, R. (2009) Emerging and reemerging zoonoses and basic principles for zoonoses control. Rev. Med. Vet., 17(1): 85-97. Available from: http:// www.scielo.org.co/scielo.php?script $=$ sci_abstract\&pi $\mathrm{d}=$ S0122-93542009000100008\&lng=en\&nrm=iso\&t1ng=es. Retrieved on 18-11-2020.

36. Bartolo, F.P., Rojas, P. and Gadickë, P. (2008) Evaluación del impacto de un programa de educación sanitaria para prevenir enfermedades zoonóticas. Theoria, 17(1): 61-69, Available from: https://www.redalyc.org/articulo. oa? $\mathrm{id}=29917107$. Retrieved on 10-06-2021.

37. Vicuña Alvarado, F. (2017) Evaluation of a playful tool in the learning of the Echinococcus granulosus zoonosis and its preventive measures in primary school students in an endemic area, Junín - Perú. Available from: https://www.repositorio.upch.edu.pe/bitstream/handle/20.500.12866/780/evaluacion_vicunaalvarado_fariva. pdf? sequence=1\&isallowed=y. Retrieved on 19-11-2020.

38. Stull, J.W., Peregrine, A.S., Sargeant, J.M. and Weese, J.S. (2013) Pet husbandry and infection control practices related to zoonotic disease risks in Ontario, Canada. BMC Public Health, 13(1): 520.

39. Abebe, F. and Fesseha, H. (2020) Assessment of community knowledge, attitude and practice on common zoonotic diseases in Jinka town, Southern Ethiopia. Gaz. Med. Sci., 1(3): 18-29.

40. Ghasemzadeh, I. and Namazi, S. (2015) Review of bacterial and viral zoonotic infections transmitted by dogs. J. Med. Life, 8(4): 1-5.

41. Boyle, S.F., Corrigan, V.K., Buechner-Maxwell, V. and Pierce, B.J. (2019) Evaluation of risk of zoonotic pathogen transmission in a university-based animal assisted intervention (AAI) program. Front. Vet. Sci., 6(1): 167.

42. Kogan, L., Schoenfeld, R. and Santi, S. (2019) Medical updates and appointment confirmations: Pet owners' perceptions of current practices and preferences. Front. Vet. Sci., 6(1): 80.

43. Hasanov, E., Zeynalova, S., Geleishvili, M., Maes, E., Tongren, E., Marshall, E., Banyard, A., McElhinney, L.M., Whatmore, A.M., Fooks, A.R. and Horton, D.L. (2018) Assessing the impact of public education on a preventable zoonotic disease: Rabies. Epidemiol. Infect., 146(2): 227-235. 